\section{Vitamin D and vitamin D receptor in patients with ophthalmic pterygium}

\author{
Cristina Maxia, ${ }^{1}$ Daniela Murtas, ${ }^{1}$ \\ Michela Corrias, ${ }^{1}$ Ignazio Zucca, ${ }^{2}$ \\ Luigi Minerba, ${ }^{3}$ Franca Piras, ${ }^{1}$ \\ Cristiana Marinelli, ${ }^{4}$ \\ Maria Teresa Perra ${ }^{1}$
}

${ }^{1}$ Department of Biomedical Sciences, University of Cagliari

${ }^{2}$ Department of Surgical Science, Eye Clinic, University of Cagliari ${ }^{3}$ Department of Public Health, Clinical and Molecular Medicine, University of Cagliari

${ }^{4}$ Laboratory of Clinical Chemistry, Hematology and Microbiology, Hospital G. Brotzu, Cagliari, Italy

\section{Abstract}

Pterygium, an ultraviolet radiation (UV)-related disease, is a relatively benign process, but since it displays tumor-like features, it has been proposed to be a neoplastic-like growth disorder. Vitamin D performs a number of functions in addition to calcium homeostasis, as inhibition of cell proliferation, activation of apoptotic pathways, and inhibition of angiogenesis. Since the antitumor actions of vitamin D are mediated primarily through the nuclear vitamin $\mathrm{D}$ receptor (VDR), the aim of the present study was to investigate vitamin $\mathrm{D}$ status in patients with pterygium and in control subjects, and VDR immunohistochemical expression in samples of pterygium and normal conjunctiva in order to evaluate a possible role of vitamin D pathway in the pathogenesis of the disease. Serum vitamin D concentration was measured among 41 patients with pterygium and 47 volunteers by an automated chemiluminescence immunoassay. Moreover, 23 formalin-fixed and paraffin-embedded pterygium biopsy samples and 24 conjunctiva specimens were treated for the immunohistochemical demonstration of VDR using the streptavidin-biotin alkaline phosphatase method. No differences were observed about vitamin D level between patient with pterygium and control group, but significant differences between VDR immunolocalization in pterygium and normal conjunctiva were observed $(\mathrm{P}=0.00001)$. In conjunctiva, the immunoreactivity, localized mainly in cytoplasm of epithelial cells, may probably demonstrate VDR regulation of cell growth, differentiation, and apoptosis, while in pterygium VDR co-localization in the nucleus and cytoplasm of epithelial cells may indicate alternative nuclear pathways by which vitamin $\mathrm{D}$ might exert its antiinflammatory and anti-proliferative effects by the regulation of gene expression.

\section{Introduction}

Pterygium is a chronic condition characterized by the encroachment of altered bulbar conjunctiva into the normal cornea. Histologically it consists of a superficial conjunctival epithelium layer and an underlying fibrovascular component, with features indicative of both degenerative process and disordered growth. Pterygium is a relatively benign process, but since it displays tumor-like features, as aggressive recurrence after removal and local invasiveness with various degrees of abnormalities, ranging from mild dysplasia to carcinoma in situ, it has been proposed to be a neoplastic-like growth disorder. As a matter of fact, several authors ${ }^{2,3}$ demonstrated that preneoplastic lesions may be associated with pterygium. Many factors have been proposed as causative agents in its pathogenesis, such as extracellular matrix remodelling, ${ }^{4}$ inflammatory process, ${ }^{5-7}$ anti-apoptotic mechanisms, ${ }^{8,9}$ cytokines, ${ }^{10}$ growth and angiogenic factors, ${ }^{11-13}$ viral infection, ${ }^{14,15}$ oxidative stress, ${ }^{16,17}$ hypoxic ischemic injury, ${ }^{18}$ anomaly in epithelial differentiation ${ }^{19}$ and wound healing defect. ${ }^{20}$ However, it is well-established that pterygium is an ultraviolet radiation (UV)-related disease. ${ }^{16,20-24}$ For a long time several authors have labelled pterygium as a chronic degenerative growth disorder, but, following the discovery of $\mathrm{p} 53$ overexpression in the epithelium, ${ }^{15,25-28}$ it is now considered as an UV-related tumor. Although its pathogenesis seems multi-factorial, chronic inflammation, angiogenesis and uncontrolled proliferation have a key role in the pathogenesis of pterygium.

Besides being taken up exogenously through dietary intake, when the skin is exposed to solar or artificial UV-B light, humans obtain endogenously a fat-soluble vitamin called vitamin D. ${ }^{29}$ The biologically active form of vitamin D, 1,25-dihydroxyvitamin $\mathrm{D}$, also known as calcitriol, plays its major physiological role in maintaining mineral ion homeostasis and regulating intestinal calcium absorption. ${ }^{30}$ In addition to its well documented role, the scientific community has focused attention in the relationship between low serum vitamin D levels and a variety of seemingly disparate
Correspondence: Dr. Cristina Maxia, Department of Biomedical Sciences, Section of Cytomorphology, University of Cagliari, Cittadella Universitaria, 09042 Monserrato (CA), Italy.

Tel. +39.070.6754005 - Fax: +39.070.675 4003 . E-mail: cmaxia@unica.it

Key words: Pterygium; conjunctiva; vitamin $\mathrm{D}$; vitamin D receptor (VDR); immunohistochemistry.

Contributions: CMaxia, DM, study conception and experiment design, data collection monitoring, data interpretation, and paper drafting and revision; $\mathrm{MC}$, experiments performing and data collection; IZ, patients selection and collection of biological materials; LM, data analysis; FP, data collection monitoring and manuscript revision; CMarinelli, experiments performing and data collection; MTP direction of the intellectual conception, research designed, data interpretation and critical manuscript revision. All authors read and approved the final version of the present research manuscript.

CMaxia, DM: These authors contributed equally to this work

Acknowledgments: The study was supported by grants from the Fondazione Banco di Sardegna (FBS), and from the Fondo Integrativo per la Ricerca (FIR) of the University of Cagliari, Italy. The authors are thankful to Mrs. Maria Itala Mosso for her skilful technical assistance. Some of the results of this work were presented at the $6^{\text {th }}$ National Congress of the Italian Society of Anatomy and Histology (SIAI) in Ferrara, Italy [abstract published in: It J Anat Embryol 2015;120(suppl. 1):47].

Conflict of interest: The authors declare no conflict of interest.

Received for publication: 28 July 2017.

Accepted for publication: 15 September 2017.

This work is licensed under a Creative Commons Attribution-NonCommercial 4.0 International License (CC BY-NC 4.0).

(C) Copyright C. Maxia et al., 2017

Licensee PAGEPress, Italy

European Journal of Histochemistry 2017; 61:2837 doi:10.4081/ejh.2017.2837

systemic conditions, including multiple sclerosis, cardiovascular disease, schizophrenia, type 1 diabetes mellitus, and infections, particularly tuberculosis and influenza. $29,31-34$

More recently, vitamin D status has been inversely associated with risk for various cancers, since vitamin D inhibits cell 
proliferation and angiogenesis, activates apoptotic pathways, and exerts pro-differentiative effects. ${ }^{35,36}$ In 1980, Garland and Garland ${ }^{37}$ reported an inverse association between sunlight exposure and colon cancer mortality, hypothesizing for vitamin $\mathrm{D}$ a protective role against the risk of colon cancer. To support these evidences, epidemiological studies have shown an association between low circulating 25-hydroxyvitamin D3 [25 OH Vitamin D; 25(OH)D] levels, a biomarker of vitamin D exposure, and increased risk for colorectal, breast and prostate cancers. ${ }^{38-40}$

The action of vitamin $\mathrm{D}$ is mediated by the nuclear vitamin D receptor (VDR), a 48 to $55 \mathrm{kD}$ activated transcription factor, expressed in various tissues, including those not involved in mineral metabolism. ${ }^{41}$ VDR is expressed by normal and neoplastic cells, and it is localized mostly in the nucleus although some authors have also reported cytoplasmic receptors. ${ }^{42,43}$ It is well-established that the lack of the active hormonal form of vitamin D or its nuclear receptor results in the development of hypocalcemia and its related clinical manifestations..$^{44,45}$

Since the antitumor actions of vitamin D are mediated primarily through VDR, and little is known about this subject in pterygium, the aim of the present study was to investigate vitamin D status in patients with pterygium and in control subjects, and VDR immunohistochemical expression in bioptic samples of pterygium and normal conjunctiva; the knowledge of vitamin D status and VDR localization may contribute to the understanding of the pathogenesis of the disease.

\section{Materials and Methods}

\section{Vitamin D status: Patients and study design}

We conducted the study on vitamin D status among 41 adults (30 males and 11 females) (age 28-82 years; mean $58.34 \pm 15.08$ ) that were admitted and treated for primary pterygium excision by bare sclera technique at the Department of Surgical Science, Eye Clinic, University of Cagliari (Sardinia, Italy), during summer 2012 and 2013. During the same periods, 47 volunteer healthy subjects ( 13 males and 34 females) (age 25-66 years; mean $43.74 \pm 11.74)$ were considered eligible as normal control subjects for this study. They were recruited among the Eye Clinic staff, their family and friends. They should not have history of pterygium and/or other ocu- lar surface diseases. Both patients and volunteers did not receive any vitamin D dietary supplement in the 6 months before the analysis, and no one reported history of pathologies related to vitamin D deficiency, such as fat malabsorption, liver disease or renal insufficiency. In Table 1 are reported the characteristics of patients selected for the evaluation of serum vitamin D concentration.

The study protocol was approved by the local Institutional Research Ethic Committee. Written informed consent was obtained from all participants prior to the initiation of the study.

Concentration of $25(\mathrm{OH}) \mathrm{D}$ in both patients and volunteers was determined at the Laboratory of Clinical Chemistry, Hematology and Microbiology, Hospital "G. Brotzu", Cagliari, by the LIAISON ${ }^{\circledR}$ $25 \mathrm{OH}$ vitamin D assay, a direct, competitive chemiluminescent immunoassay (CLIA) for quantitative determination of total $25 \mathrm{OH}$ vitamin $\mathrm{D}$ in serum or plasma (DiaSorin LIAISON ${ }^{\circledR}$, Stillwater, MN, USA), following the experimental protocol optimized by DiaSorin Inc.:46 "During the first incubation, $25 \mathrm{OH}$ vitamin $\mathrm{D}$ is dissociated from its binding protein and binds to the specific antibody on the solid phase. After 10 min the tracer (vitamin D linked to an isoluminol derivative) is added. After an additional 10 min incubation, the unbound material is removed with a wash cycle. Subsequently, the starter reagents are added to initiate a flash chemiluminescent reaction. The light signal is measured by a photomultiplier as relative light units (RLU) and is inversely proportional to the concentration of $25 \mathrm{OH}$ vitamin D present in calibrators, controls, or samples."

The scientific community recommends the following ranges for the classification of
$25-\mathrm{OH}$ vitamin D status, as reported in DiaSorin LIAISON ${ }^{\circledR}$ datasheet: deficiency, with $25(\mathrm{OH}) \mathrm{D}$ plasma concentration $<10$ $\mathrm{ng} / \mathrm{mL}$ (level 1); insufficiency, between 10$30 \mathrm{ng} / \mathrm{mL}$ (level 2); sufficiency, between $30-100 \mathrm{ng} / \mathrm{mL}$ (level 3) and toxicity, with 25(OH)D level >100 ng/mL (level 4).

\section{VDR immunohistochemistry: Patients and study design}

Among the group of 41 patients admitted and treated for primary pterygium excision, only 23 specimens were processed for paraffin embedding; moreover, 24 exposed bulbar conjunctiva biopsy samples, collected from patients without pterygium (nonpterygium subjects), who underwent cataract and strabismus surgery at the Eye Clinic, were formalin-fixed and paraffin embedded and used as normal controls. Most of pterygium were located on the nasal side and only the head of the lesion was used as bioptic sample. The study included 16 inflamed and 7 quiescent lesions, and pterygium morphology was clinically graded as atrophic (6 cases), intermediate (13 cases), or fleshy (4 cases) according to an assessment of pterygium translucency. In both groups, the vitamin D status was assessed. Patients did not receive any medication before surgery except for a topical anaesthetic, and no drugs or chemical agents were used during surgical operation. Complete demographic and clinical information on patients was available in all cases (Table 2).

Microtome histological sections (6-7 $\mu \mathrm{m}$ thick) were treated for the immunohistochemical demonstration of VDR using the streptavidin-biotin alkaline phosphatase method. They were dewaxed in xylene and rehydrated in a graded alcohol series and phosphate-buffered saline (PBS). Water

Table 1. Characteristics of patients selected for the evaluation of serum vitamin D concentration.

$\begin{array}{lcc} & \begin{array}{c}\text { Pterygium } \\ (\mathrm{n}=41)\end{array} & \begin{array}{c}\text { Healthy subjects } \\ (\mathrm{n}=47)\end{array} \\ \text { Mean age }( \pm \mathrm{SD}) & 58.34( \pm 15.09) & 43.74( \pm 11.74) \\ \text { Age range }(\mathrm{yrs}) & 28-82 & 25-66 \\ \text { Sex }(\%) & 30(73) & 13(28) \\ \quad \text { Male } & 11(27) & 34(72) \\ \quad \text { Female } & & \\ \text { Location of the lesion }(\mathrm{M} / \mathrm{F}) & 28(19 / 9) & \\ \quad \text { Nasal side } & 13(11 / 2) & \\ \text { Temporal side } & \end{array}$

Serum 25(OH)D

\begin{tabular}{|c|c|}
\hline Mean \pm SD $(n g / m L)$ & $19.47 \pm 7.37$ \\
\hline
\end{tabular}

*Student's $t$-test. 
bath heating-based antigen retrieval was performed by immersion in $10 \mathrm{mM}$ citrate buffer solution $(\mathrm{pH} 6.0)$ at $95^{\circ} \mathrm{C}$ for $30 \mathrm{~min}$. After gradual cooling for $20 \mathrm{~min}$, sections were treated for 45 min with $10 \%$ normal goat serum in PBS. Mouse monoclonal antibody (1:100, clone D6, Santa Cruz Biotechnology Inc., Dallas, TX, USA) to human VDR, raised against amino acids 344-424, which possesses the highest specificity, sensitivity, and versatility, ${ }^{47}$ was used as primary antiserum and incubated overnight at $4^{\circ} \mathrm{C}$. Biotinylated anti-mouse IgG was used as secondary antiserum (1:800; Vector Laboratories, Burlingame, CA, USA) and incubated for $30 \mathrm{~min}$ at room temperature; the sections were further incubated in alkaline phosphatase streptavidin (1:1000; Vector Laboratories) for $30 \mathrm{~min}$ at room temperature and reacted with Fast Red Substrate System (Dako, Glostrup, Denmark). All sections were thoroughly rinsed in PBS between each step, and finally counterstained with Mayer hematoxylin and mounted in glycerol gelatin (Sigma, St. Louis, MO, USA).

Sections of an archival biopsy specimen of prostate were used as positive control tissue; negative controls were obtained by omission of the primary antibody or by replacing the primary antibody with an isotype-matched antibody. Positive and negative controls were run simultaneously.

Micrographs were captured by a Lumenera's INFINITY 3-1 digital camera on a microscope Zeiss Axiophot (Carl Zeiss Inc., Oberkochen, Germany), and processed by Adobe Photoshop (ver. 7.0; Adobe Systems, Inc., San Jose, CA, USA) software.

\section{Evaluation of immunoreactivity}

Results were independently evaluated by three observers (CM, DM, MTP) in a blinded fashion, as described in our previous paper: ${ }^{7}$ Four to six 200x fields covering almost the whole of each of the four sections per sample were examined with a 144intersection point square reticulum $(0.78$ $\mathrm{mm}^{2}$ ) inserted in the eyepiece and scored for the percentage of epithelial immunoreactive cells. In each sample, it was evaluated if the staining was localized only in nucleus, only in cytoplasm or both in nucleus and cytoplasm of epithelial cells. The intensity of VDR staining was graded $0,1+$, $2+, 3+$. The VDR protein was considered to be highly expressed if $10 \%$ or more of the cells stained with an intensity score of $2+$ or $3+$, as described in 2014 by Zhou et al. ${ }^{48}$ in esophageal adenocarcinoma and precancerous lesions.

\section{Statistical analysis}

The results of the evaluation of $25(\mathrm{OH}) \mathrm{D}$ plasma mean concentration and of the VDR immunohistochemical analysis were analyzed by Student's $t$-test and Fisher's exact test, respectively. Data were computed by the IBM $^{\circledR}$ SPSS $^{\circledR}$ Statistics 21.0. The tests used were two-tailed. A P value $\leq 0.05$ was considered statistically significant.

\section{Results}

\section{Vitamin D status}

Among the 41 patients with pterygium and the 47 healthy subjects of the control group, the mean concentration of plasma 25(OH)D was $19.47 \mathrm{ng} / \mathrm{mL} \pm 7.37$ (median $18.7 \mathrm{ng} / \mathrm{mL}$, range $5.82-35.4 \mathrm{ng} / \mathrm{mL})$ and $18.22 \mathrm{ng} / \mathrm{mL} \pm 8.01$ (median $15.8 \mathrm{ng} / \mathrm{mL}$, range $7.92-45.2 \mathrm{ng} / \mathrm{mL}$ ) respectively (Table 1 ). Among pterygium patients, only 5 people (12\%) had level 3 concentration, while 32 patients had level $2(78 \%)$ and 4 subjects had level $1(10 \%)$. No patients showed toxic concentrations of vitamin D (Table 3). Regarding the $25(\mathrm{OH}) \mathrm{D}$ plasma mean concentration, no statistical differences between pterygium and control group were observed, as assessed by Student's $t$-test $(\mathrm{P}>0.05)$.

\section{VDR immunohistochemistry}

Immunohistochemical analysis of VDR expression in the 23 pterygium specimens showed a moderate to strong immunoreactivity of the epithelial cells, being localized in both nucleus and cytoplasm (Figure 1A) in 19 samples $(83 \%)$, while in 3 samples $(13 \%)$ the immunostaining was detected only in cytoplasm (Table 4). One specimen (4\%) did not show any immunoreactivity. No specimens showed exclusively nuclear staining. In the reactive samples, the nuclear staining was always stronger than the cytoplasmic. In most samples, a marked VDR immunostaining was also detected in epithelial goblet cells (Figure 1A) and in the endothelial cells of sub-epithelial microvessels (Figure 1A,C). Scattered immunoreactive leucocytes-like cells, morphologically

Table 2. Characteristics of patients selected for the immunohistochemical localization of vitamin $\mathrm{D}$ receptor.

\begin{tabular}{|c|c|c|c|}
\hline & $\begin{array}{l}\text { Pterygium } \\
\text { (n=23) }\end{array}$ & $\begin{array}{l}\text { Non-pterygium subjects } \\
\qquad(\mathrm{n}=24)\end{array}$ & P value* \\
\hline Mean age $( \pm$ SD $)$ & $56.04( \pm 16.4)$ & $38.87( \pm 19.61)$ & \\
\hline Age range (yrs) & 28-82 & 13-78 & \\
\hline $\begin{array}{l}\text { Sex }(\%) \\
\text { Male } \\
\text { Female }\end{array}$ & $\begin{array}{l}16(70) \\
7(30)\end{array}$ & $\begin{array}{c}8(33) \\
16(67)\end{array}$ & \\
\hline $\begin{array}{l}\text { Location of the lesion }(\mathrm{M} / \mathrm{F}) \\
\text { Nasal side } \\
\text { Temporal side }\end{array}$ & $\begin{array}{c}18(11 / 7) \\
5(5 / 0)\end{array}$ & & \\
\hline $\begin{array}{l}\text { Grade } \\
\quad \text { Atrophic } \\
\text { Intermediate } \\
\text { Fleshy }\end{array}$ & $\begin{array}{c}6 \\
13 \\
4\end{array}$ & & \\
\hline $\begin{array}{l}\text { Disease stage } \\
\text { Inflamed } \\
\text { Quiescent }\end{array}$ & $\begin{array}{c}16 \\
7\end{array}$ & & \\
\hline
\end{tabular}

Serum 25(OH)D

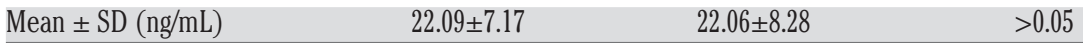

*Student's $t$-test.

Table 3. Evaluation of serum vitamin D concentration among patients with pterygium and the control group.

\begin{tabular}{|c|c|c|c|c|c|c|}
\hline \multirow[b]{2}{*}{$25(\mathrm{OH}) \mathrm{D}$} & \multicolumn{3}{|c|}{ Pterygium (n. 41) } & \multicolumn{3}{|c|}{ Healthy subjects (n. 47) } \\
\hline & $\begin{array}{c}\text { Patients } \\
(\mathrm{n}, \%)\end{array}$ & $\begin{array}{c}\text { Mean } \pm \text { SD } \\
(\mathrm{ng} / \mathrm{mL})\end{array}$ & $\begin{array}{l}\text { Median } \\
\text { (ng/mL) }\end{array}$ & $\begin{array}{c}\text { Patients } \\
\text { (n, \%) }\end{array}$ & $\begin{array}{c}\text { Mean } \pm \text { SD } \\
(\mathrm{ng} / \mathrm{mL})\end{array}$ & $\begin{array}{l}\text { Median } \\
\text { (ng/mL) }\end{array}$ \\
\hline Toxic & --- & --- & --- & --- & --- & --- \\
\hline Sufficient & $5(12)$ & $31.9 \pm 2.18$ & 31 & $5(11)$ & $36.12 \pm 5.26$ & 34.9 \\
\hline Insufficient & $32(78)$ & $18.97 \pm 5.17$ & 18.25 & $38(81)$ & $16.82 \pm 4.75$ & 15.7 \\
\hline Deficient & $4(10)$ & $7.89 \pm 1.71$ & 8.1 & $4(8)$ & $9.16 \pm 0.84$ & 9.5 \\
\hline
\end{tabular}


recognizable as cells belonging to the "mononuclear phagocyte system (MPS)", were found in the subepithelial connective tissue (Figure 1C) and inside the vessels (Figure 1D). The mean concentration of $25(\mathrm{OH}) \mathrm{D}$ in patients with pterygium was $22.09 \mathrm{ng} / \mathrm{mL} \pm 7.17$ (median $20.7 \mathrm{ng} / \mathrm{mL}$, range 11.8-35.4 ng/mL) (Table 2). Among the normal conjunctival samples, 16 (67\%) exhibited mainly a cytoplasmic staining for VDR (Figure 1B) in the epithelial cells, while only 2 samples ( $8 \%$ ) displayed both nuclear and cytoplasmic immunoreaction (Table 4); six specimens (25\%) showed no immunostaining. The mean concentration of $25(\mathrm{OH}) \mathrm{D}$ in these patients was 22.06 $\mathrm{ng} / \mathrm{mL} \pm 8.28$ (median $21.7 \mathrm{ng} / \mathrm{mL}$, range 7.4-34.9 ng/mL) (Table 2).

The Vitamin D concentration detected in the non-pterygium subjects was comparable to that of the healthy subjects. Most conjunctivas displayed mainly mild to moderate staining, while in pterygium the immunoreaction was always more intense. In the negative control sections the immunoreactivity was completely abolished (Figure 1F).

Regardless of vitamin D status ( $P>0.05$ ), significant differences between VDR immunohistochemical localization in pterygium and normal conjunctiva were noticed, as assessed by Fisher's exact test $(\mathrm{P}=0.00001)$ (Table 4). Moreover, in pterygium no correlation between VDR expression and demographic or clinical parameters (age, gender, location, disease stage and grade) was observed $(\mathrm{P}>0.05)$.

\section{Discussion}

Holick $^{49}$ refers to vitamin D deficiency as pandemic because of its global spread, almost induced by chronically inadequate sun exposure. Such deficiency is associated with harmful effects, including a predisposition to cancer on almost all tissues. In Europe, vitamin D status varies according to latitude, season and skin pigmentation. Serum $25(\mathrm{OH}) \mathrm{D}$ is higher in people living in Northern than Southern European countries and higher in Western than Eastern Europe. ${ }^{50}$ We investigated about vitamin D status in people living in Sardinia, an island in the centre of the Mediterranean Sea, characterized by high ultraviolet radiation level. ${ }^{51}$ Our results demonstrate that both pterygium and control group showed insufficient level of plasma vitamin $\mathrm{D}$. The reason of such suboptimal vitamin D concentration in a population with high insolation level has not been well understood yet; it may be linked to more skin pigmentation and sunshine avoiding behaviour, as in Spain, Greece and other parts of Italy, ${ }^{50}$ but it might be also due to the well-known genetic peculiarity of Sardinians. Several anthropologists ${ }^{52,53}$ define Sardinians as "the most differentiated population in the Mediterranean basin, as the result of genetic

drift and geographic isolation, with a limited genetic impact from conquests of the island during history". In our study, no statistical difference between patients with pterygium and control group were observed, hence it seems that there is not a direct correlation between vitamin $\mathrm{D}$ defi-

Table 4. Immnunohistochemical localization of vitamin $\mathrm{D}$ receptor in pterygium and normal conjunctiva.

\begin{tabular}{lccc}
\hline Localivation Pterygium (positive/total) & Conjunctiva (positive/total) & P value* \\
Cytoplasm & $3 / 23$ & $16 / 24$ & 0.0001 \\
\hline Nucleus and cytoplasm & $19 / 23$ & $2 / 24$ & \\
\hline
\end{tabular}

*Fisher's exact test.
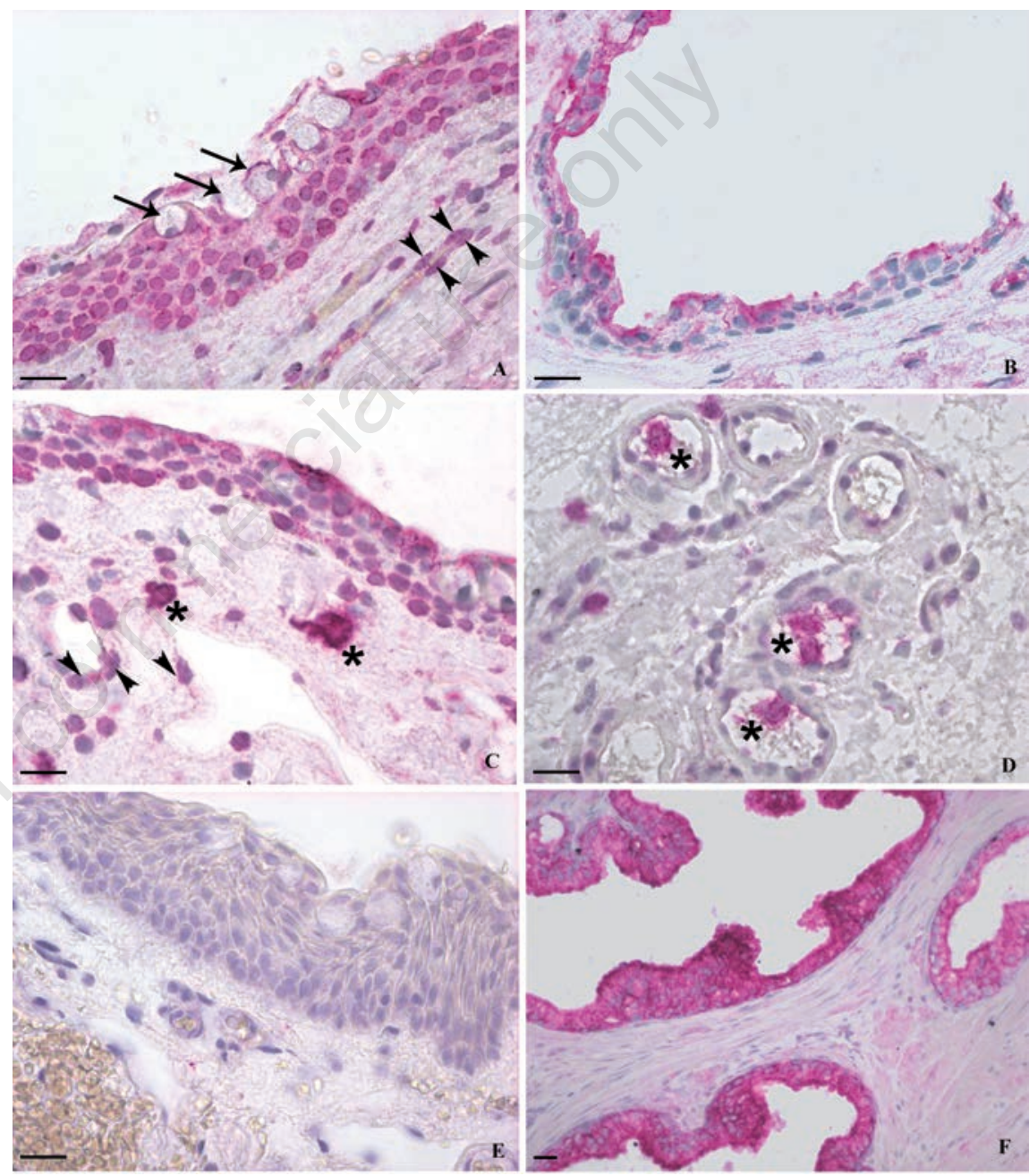

Figure 1. Immunohistochemical staining of VDR. A,C,D,E) Pterygium; B) normal conjunctiva; F) human prostate. Pterygium showed a moderate to strong immunoreactivity of the epithelial cells, mostly localized in both nucleus and cytoplasm (A), while conjunctival epithelium exhibited mainly a mild to moderate cytoplasmic staining (B). In pterygium, the nuclear staining was always stronger than the cytoplasmic. A marked VDR immunoreaction was also detected in epithelial goblet cells (A) (arrows) and in the endothelial cells of sub-epithelial microvessels (A,C) (arrowheads). Scattered immunoreactive leucocytes-like cells, morphologically recognizable as cells belonging to the "mononuclear phagocyte system (MPS)", were found in the subepithelial connective tissue $(C)$ and inside the vessels (D) (asterisks). Negative (E) and positive (F) control sections. Scale bars: $20 \mu \mathrm{m}$. 
ciency and the pathogenesis of pterygium. However, in a recent paper, Jee et al. ${ }^{54}$ demonstrated a positive association between blood 25(OH)D level and Korean pterygium, but the exact mechanism is unknown. Such discrepancy with the results of our study may be related to the great number of samples they examined, but also to the above-mentioned Sardinian genetic peculiarity. Probably in Sardinia the high insolation rate, on one side, may be an important etiopathogenetic factor for the occurrence of pterygium, which is characterized by chronic inflammation, angiogenesis and uncontrolled proliferation; on the other side, UV rays may not be able to stimulate the production of adequate vitamin D amount in Sardinians, that would be insufficient to exert its protective action against the harmful effects of UV rays on conjunctiva.

Since the action of vitamin D is mediated by the nuclear VDR, expressed by normal and neoplastic cell, we examined VDR expression in bioptic samples of pterygium and normal conjunctiva. In our study, most pterygium samples (19/23, 83\%) showed a moderate to strong VDR immunoreactivity, localized in both nucleus and cytoplasm of epithelial cells; nuclear staining was always more intense than the cytoplasmic. Among the normal conjunctival samples, epithelial cells exhibited mainly a mild to moderate cytoplasmic staining for VDR (16/24, $67 \%$ ). Then, regardless of vitamin D status, similar in both groups of patients, significant differences between VDR immunolocalization in pterygium and normal conjunctiva were noticed; such differences may be linked to the different role of activated VDR in cytoplasm and nucleus. The differences in VDR immunolocalization might be explained considering that in normal conjunctiva vitamin D might regulate cell growth, differentiation and apoptosis by a cytoplasmic pathway; ${ }^{55}$ in pterygium, VDR nuclear staining may represent an alternative nuclear pathway by which vitamin D might exert its anti-inflammatory and antiproliferative effects by the regulation of gene expression. ${ }^{56,57}$ But this is just a theory, because the low vitamin $\mathrm{D}$ amount, maybe due to genetic factors, could be insufficient to exert its anti-inflammatory action against the effects of UV rays on conjunctiva. It is well-known that vitamin $\mathrm{D}$ is an immunomodulator that can reduce the production of pro-inflammatory cytokines and increase the production of anti-inflammatory cytokines, ${ }^{58}$ thus modifying the innate immune response of the body. Dysregulation of VDR may lead to exaggerated inflammatory responses; ${ }^{59}$ maybe defects in vitamin D and VDR pathways could sustain the condition of chronic inflammation typical of pterygium.

Besides to the well-known pro-apoptotic effects, following UV-trauma vitamin D may have also an anti-apoptotic effect resulting in increased cell survival. Then it is quite clear that cell fate may depend on cellular context, which can be able to address VDR pathway. ${ }^{60}$ These considerations would be in agreement with a previous study by Tan et al. ${ }^{6}$ who classify pterygium as an UV-related benign condition in which the uncontrolled proliferation is the result of a disorder of apoptosis occurring in conjunctiva; it would also support the results of previous papers ${ }^{7,61}$ which propose that in pterygium the concomitant overexpression of survivin, an anti-apoptotic protein, and functional loss of p53 might be the basis for an aberrant inhibition of apoptosis.

Moreover, in our pterygium samples, a marked VDR immunostaining was also detected in the endothelial cells of subepithelial microvessels, probably because of the role of calcitriol in the regulation of endothelial cell proliferation and differentiation. ${ }^{62-64}$ Scattered immunoreactive leucocytes-like cells, morphologically recognizable as cells belonging to the "mononuclear phagocyte system (MPS)", were found in the subepithelial connective tissue of pterygium and inside the vessels, probably because of the role of vitamin D in the regulation of the immune system. ${ }^{65,66}$ In fact, in our previous report ${ }^{5}$ we studied the distribution of the immunocompetent cells in pterygium, suggesting that all the effector components of the mucosal immune system, including cells of MPS, are present, and, therefore, demonstrating that an immunopathogenetic mechanism seems to be involved in the pathogenesis of pterygium. Our results on the presence of VDR in leucocyte-like cells are supported by the concept that the induction of VDR by vitamin $\mathrm{D}$ occurs in monocytes and, to a lesser degree, in mature macrophages ${ }^{67}$ and that vitamin D seems to induce the differentiation of monocytes to macrophagse and to enhance the monocyte function in antigen presentation. ${ }^{68}$

Finally, the finding of VDR immunoreactivity in cytoplasm of epithelial goblet cells in both conjunctiva and pterygium is in agreement with the study by Paz et al. ${ }^{69}$ on the role of calcium in mucin packaging within conjunctival goblet cells. Then conjunctiva, as skin, ${ }^{70}$ may represent an important target tissue for vitamin $\mathrm{D}$, in which it may regulate keratinocytes growth and mucus packaging in goblet cells through the binding to VDR.

\section{References}

1. Coroneo MT, Di Girolamo N, Wakefield D. The pathogenesis of pterygia. Curr Opin Ophthalmol 1999;10:282-8.

2. Perra MT, Colombari R, Maxia C, Zucca I, Piras F, Corbu A, et al. Finding of conjunctival melanocytic pigmented lesions within pterygium. Histopathology 2006;48:387-93.

3. Chui J, Coroneo MT, Tat LT, Crouch R, Wakefield D, Di Girolamo N. Ophthalmic pterygium: a stem cell disorder with premalignant features. Am J Pathol 2011;178:817-27.

4. Di Girolamo N, McCluskey P, Lloyd A, Coroneo MT, Wakefield D. Expression of MMPs and TIMPs in human pterygia and cultured pterygium epithelial cells. Invest Ophthalmol Vis Sci 2000;41: 671-9.

5. Perra MT, Maxia C, Zucca I, Piras F, Sirigu P. Immunohistochemical study of human pterygium. Histol Histopathol 2002;17:139-49.

6. Maxia C, Perra MT, Demurtas P, Minerba L, Murtas D, Piras F, et al. Relationship between the expression of cyclooxygenase- 2 and survivin in primary pterygium. Mol Vis 2009;15:458-63.

7. Demurtas P, Di Girolamo N, Corrias M, Zucca I, Maxia C, Diana A, et al. Immunohistochemical analysis of angiotensin converting enzyme in Sardinian pterygium. Histol Histopathol 2013;28:759-66.

8. Tan DT, Tang WY, Liu YP, Goh HS, Smith DR. Apoptosis and apoptosis related gene expression in normal conjunctiva and pterygium. $\mathrm{Br} J$ Ophthalmol 2000;84:212-6.

9. Maxia C, Perra MT, Demurtas P, Minerba L, Murtas D, Piras F, et al. Expression of survivin protein in pterygium and relationship with oxidative DNA damage. J Cell Mol Med 2008; 12 : 2372-80.

10. Di Girolamo N, Kumar RK, Coroneo MT, Wakefield D. UVB-mediated induction of interleukin- 6 and -8 in pterygia and cultured human pterygium epithelial cells. Invest Ophthalmol Vis Sci 2002;43:3430-7.

11. Kria L, Ohira A, Amemiya T. Growth factors in cultured pterygium fibroblasts: immunohistochemical and ELISA analysis. Graefes Arch Clin Exp Ophthalmol 1998;236:702-8.

12. Ribatti D, Nico B, Maxia C, Longo V, Murtas D, Mangieri D, et al. Neovascularization and mast cells with tryptase activity increase simultaneous- 
ly in human pterygium. J Cell Mol Med 2007;11:585-9.

13. Ribatti D, Nico B, Perra MT, Maxia C, Piras F, Murtas D, et al. Correlation between NGF/TrkA and microvascular density in human pterygium. Int J Exp Pathol 2009;90:615-20.

14. Detorakis ET, Drakonaki EE, Spandidos DA. Molecular genetic alterations and viral presence in ophthalmic pterygium. Int J Mol Med 2000;6:35-41.

15. Piras F, Moore PS, Ugalde J, Perra MT, Scarpa A, Sirigu P. Detection of human papillomavirus DNA in pterygia from different geographical regions. $\mathrm{Br} \mathrm{J}$ Ophthalmol 2003;87:864-66.

16. Perra MT, Maxia C, Corbu A, Minerba L, Demurtas P, Colombari R, et al. Oxidative stress in pterygium: relationship between p53 and 8-hydroxydeoxyguanosine. Mol Vis 2006;12: 1136-42.

17. Tsai YY, Cheng YW, Lee H, Tsai FJ, Tseng SH, Lin CL, et al. Oxidative DNA damage in pterygium. Mol Vis 2005;11:71-5.

18. Kim KW, Ha HS, Kim JC. Ischemic tissue injury and progenitor cell tropism: significant contributors to the pathogenesis of pterygium. Histol Histopathol 2015;30:311-20.

19. Riau AK, Wong TT, Beuerman RW, Tong L. Calcium-binding S100 protein expression in pterygium. Mol Vis 2009;15:335-42.

20. Chui J, Di Girolamo N, Wakefield D, Coroneo MT. The pathogenesis of pterygium: current concepts and their therapeutic implications. Ocul Surf 2008;6:24-43.

21. Chiang CC, Cheng YW, Lin CL, Lee H, Tsai FJ, Tseng SH, et al. Cyclooxygenase 2 expression in pterygium. Mol Vis 2007;13:635-8.

22. Di Girolamo N, Wakefield D, Coroneo MT. UVB-mediated induction of cytokines and growth factors in pterygium epithelial cells involves cell surface receptors and intracellular signaling. Invest Ophthalmol Vis Sci 2006;47:2430-7.

23. Detorakis ET, Zafiropoulos A, Arvanitis DA, Spandidos DA. Detection of point mutations at codon 12 of KI-ras in ophthalmic pterygia. Eye 2005;19:210-4.

24. Reisman D, McFadden JW, Lu G. Loss of heterozygosity and p53 expression in pterygium. Cancer Lett 2004;206:7783.

25. Dushku N, Reid TW. P53 expression in altered limbal basal cells of pingueculae, pterygia, and limbal tumors. Curr Eye Res 1997;16:1179-92.
26. Tan DT, Lim AS, Goh HS, Smith DR. Abnormal expression of the p53 tumor suppressor gene in the conjunctiva of patients with pterygium. Am J Ophthalmol 1997;123:404-5.

27. Tsai YY, Cheng YW, Lee H, Tsai FJ, Tseng SH, Chang KC. P53 gene mutation spectrum and the relationship between gene mutation and protein levels in pterygium. Mol Vis 2005;11:50-5.

28. Schneider BG, John-Aryankalayil M, Rowsey JJ, Dushku N, Reid TW. Accumulation of $\mathrm{p} 53$ protein in pterygia is not accompanied by TP53 gene mutation. Exp Eye Res 2006;82:91-8.

29. Shahriari M, Kerr PE, Slade K, GrantKels JE. Vitamin D and the skin. Clin Dermatol 2010;28:663-8.

30. Jones G, Strugnell SA, DeLuca HF. Current understanding of the molecular actions of vitamin D. Physiol Rev 1998;78:1193-231.

31. Munger KL, Levin LI, Hollis BW, Howard NS, Ascherio A. Serum 25hydroxyvitamin D levels and risk of multiple sclerosis. JAMA 2006;296: 2832-8.

32. Scragg R, Sowers M, Bell C. Serum 25hydroxyvitamin $\mathrm{D}$, diabetes, and ethnicity in the Third National Health and Nutrition Examination Survey. Diabetes Care 2004;27:2813-8.

33. Cannell JJ, Vieth R, Umhau JC, Holick MF, Grant WB, Madronich S, Garland $\mathrm{CF}$, Giovannucci E. Epidemic influenza and vitamin D. Epidemiol Infect 2006;134:1129-40.

34. van der Mei IA, Ponsonby AL, Dwyer T, Blizzard L, Simmons R, Taylor BV, et al. Past exposure to sun, skin phenotype and risk of multiple sclerosis: casecontrol study. Br Med J 2003;327:16.

35. Giovannucci E. The epidemiology of vitamin $\mathrm{D}$ and cancer incidence and mortality: a review (United States). Cancer Causes Control 2005;16:83-95.

36. Pilz S, Tomaschitz A, ObermayerPietsch B, Dobnig H, Pieber TR. Epidemiology of vitamin D insufficiency and cancer mortality. Anticancer Res 2009;29:3699-704.

37. Garland CF, Garland FC. Do sunlight and vitamin $\mathrm{D}$ reduce the likelihood of colon cancer? Int $\mathrm{J}$ Epidemiol 1980;9:227-31.

38. Garland CF, Comstock GW, Garland FC, Helsing KJ, Shaw EK, Gorham ED. Serum 25-hydroxyvitamin D and colon cancer: Eight year prospective study. Lancet 1989;2:1176-8.

39. Bertone-Johnson ER, Chen WY, Holick MF, Hollis BW, Colditz GA, Willett WC, et al. Plasma 25-hydroxyvitamin D and 1,25-dihydroxyvitamin D and risk of breast cancer. Cancer Epidemiol Biomarkers Prev 2005;14:1991-7.

40. Ahonen MH, Tenkanen L, Teppo L, Hakama M, Tuohimaa P. Prostate cancer risk and prediagnostic serum 25-hydroxyvitamin D levels (Finland). Cancer Causes Control 2000;11:847-52.

41. Li YC, Pirro AE, Amling M, Delling G, Baron R, Bronson R, et al. Targeted ablation of the vitamin $\mathrm{D}$ receptor: an animal model of vitamin D-dependent rickets type II with alopecia. Proc Natl Acad Sci USA 1997;94:9831-5.

42. Srinivasan M, Parwani AV, Hershberger PA, Lenzner DE, Weissfeld JL. Nuclear vitamin $\mathrm{D}$ receptor expression is associated with improved survival in nonsmall cell lung cancer. J Steroid Biochem Mol Biol 2011;123:30-6.

43. Huhtakangas JA, Olivera CJ, Bishop JE, Zanello LP Norman AW. The vita$\min \mathrm{D}$ receptor is present in caveolaeenriched plasma membranes and binds 1 alpha,25(OH)2-vitamin D3 in vivo and in vitro. Mol Endocrinol 2004;18: 2660-71.

44. Dostal LA, Toverud SU. Effect of vitamin D3 on duodenal calcium absorption in vivo during early development. Am J Physiol 1984;246:G528-34.

45. Li YC, Amling M, Pirro AE, Priemel M, Meuse J, Baron R, et al. Normalization of mineral ion homeostasis by dietary means prevents hyperparathyroidism, rickets, and osteomalacia, but not alopecia in vitamin D receptor-ablated mice. Endocrinology 1998;139:4391-6.

46. DiaSorin Inc. 2012. LIAISON ${ }^{\circledR} 25 \mathrm{OH}$ Vitamin D TOTAL Assay. Available from: https://www.accessdata.fda.gov/ cdrh_docs/pdf11/K112725.pdf

47. Wang Y, Becklund BR, DeLuca HF. Identification of a highly specific and versatile vitamin D receptor antibody. Arch Biochem Biophys 2010;494:16677.

48. Zhou Z, Xia Y, Bandla S, Zakharov V, $\mathrm{Wu}$ S, Peters J, et al. Vitamin D receptor is highly expressed in precancerous lesions and esophageal adenocarcinoma with significant sex difference. Hum Pathol 2014;45:1744-51.

49. Holick MF. The vitamin D deficiency pandemic and consequences for nonskeletal health: mechanisms of action. Mol Aspects Med 2008;29:361-8.

50. van Schoor NM, Lips P. Worldwide vitamin D status. Best Pract Res Clin Endocrinol Metab 2011;25:671-80.

51. Demurtas $P$, Orrù G, Coni $P$, Minerba L, Corrias M, Sirigu P, et al. Association between the ACE insertion/deletion 
polymorphism and pterygium in Sardinian patients: a population based case-control study. BMJ Open 2014;4:e005627.

52. Moral P, Memmi M, Varesi L, Mameli GE, Succa V, Gutierrez B, et al. Study on the variability of seven genetic serum protein markers in Corsica (France). Anthropol Anz 1996;54:97107.

53. Calò CM, Melis A, Vona G, Piras IS. Sardinian population (Italy): a genetic review. Int J Mod Anthrop 2008;1:1121.

54. Jee D, Kim EC, Cho E, Arroyo JG. Positive association between Blood 25hydroxyvitamin D levels and pterygium after control for sunlight exposure. PLoS One 2016;11: e0157501.

55. Vuolo L, Di Somma C, Faggiano A, Colao A. Vitamin D and cancer. Front Endocrinol (Lausanne) 2012;3:58.

56. Deeb KK, Trump DL, Johnson CS. Vitamin D signalling pathways in cancer: potential for anticancer therapeutics. Nat Rev Cancer 2007;7:684-700.

57. Barsony J, Renyi I, McKoy W. Subcellular distribution of normal and mutant vitamin D receptors in living cells. Studies with a novel fluorescent ligand. J Biol Chem 1997;272:5774-82.

58. Colotta F, Jansson B, Bonelli F. Modulation of inflammatory and immune responses by vitamin D. J
Autoimmun 2017. pii: S08968411(17)30463-8 [Epub ahead of print].

59. Sun J. Vitamin D and mucosal immune function. Curr Opin Gastroenterol 2010;26:591-5.

60. Stambolsky P, Tabach Y, Fontemaggi G, Weisz L, Maor-Aloni R, Siegfried Z, et al. Modulation of the vitamin D3 response by cancer-associated mutant p53. Cancer Cell 2010;17:273-85.

61. Xu YX, Zhang LY, Zou DL, Liu ZS, Shang XM, Wu HP, et al. Differential expression and function of survivin during the progress of pterygium. Invest Ophthalmol Vis Sci 2014;55:8480-7.

62. Merke J, Milde P, Lewicka S, Hügel U, Klaus G, Mangelsdorf DJ, et al. Identification and regulation of 1,25dihydroxyvitamin D3 receptor activity and biosynthesis of 1,25-dihydroxyvitamin D3. Studies in cultured bovine aortic endothelial cells and human dermal capillaries. J Clin Invest 1989;83:190315.

63. Mantell DJ, Owens PE, Bundred NJ, Mawer EB, Canfield AE. 1 alpha,25dihydroxyvitamin D3 inhibits angiogenesis in vitro and in vivo. Circ Res 2000;87:214-20.

64. Chung I, Han G, Seshadri M, Gillard BM, Yu WD, Foster BA, et al. Role of vitamin $\mathrm{D}$ receptor in the antiproliferative effects of calcitriol in tumorderived endothelial cells and tumor angiogenesis in vivo. Cancer Res 2009; 69:967-75.

65. Wang Y, Zhu J, DeLuca HF. Where is the vitamin D receptor? Arch Biochem Biophys 2012;523:123-33.

66. Nagy L, Szanto A, Szatmari I, Széles L. Nuclear hormone receptors enable macrophages and dendritic cells to sense their lipid environment and shape their immune response. Physiol Rev 2012;92:739-89.

67. Kreutz M, Andreesen R, Krause SW, Szabo A, Ritz E, Reichel H. 1,25-dihydroxyvitamin D3 production and vitamin D3 receptor expression are developmentally regulated during differentiation of human monocytes into macrophages. Blood 1993;82:1300-7.

68. Nakamura K, Takahashi T, Sasaki Y, Tsuyuoka R, Okuno Y, Kurino M, et al. 1,25-dihydroxyvitamin D3 differentiates normal neutrophilic promyelocytes to monocytes/ macrophages in vitro. Blood 1996;87:2693-701.

69. Paz HB, Tisdale AS, Danjo Y, SpurrMichaud SJ, Argüeso P, Gipson IK. The role of calcium in mucin packaging within goblet cells. Exp Eye Res 2003;77:69-75.

70. Reichrath J, Reichrath S, Heyne K, Vogt $\mathrm{T}$, Roemer K. Tumor suppression in skin and other tissues via cross-talk between vitamin D- and p53-signaling. Front Physiol 2014;5:166. 